\title{
PERAN KEPEMILIKAN INSTITUSIONAL DALAM HUBUNGAN MANAJEMEN LABA DAN NILAI PERUSAHAAN
}

\author{
Agus Satrya Wibowo ${ }^{1}$ \\ ${ }^{1}$ Universitas Palangkaraya \\ Corresponding Author: satrya.upr@gmail.com
}

\begin{abstract}
This study aims to prove whether institutional ownership can reduce the impact of earnings management practices on firm value. Earnings management is proxied by accrual management, real activity manipulations based on abnormal production costs and abnormal discretionary expenses. Meanwhile, firm value is proxied by the metrics developed by Rhodes-Kropf et al (2005) which have the advantage of detecting misvaluation. The sample is manufacturing companies on the Indonesia Stock Exchange which have institutional ownership. The research period for 2010-2018 with panel data 410 samples observation. The findings show that institutional ownership can mitigate the effect of earnings management on firm value. Surprisingly, finding is that real activity manipulations based on abnormal discretionary expenses have the potential to destroy firm value. In other words, the market is penalizing the value of the company. These results contribute to the insight that the importance of the role of institutional ownership is to reduce information asymmetry in preventing the destruction of firm value. Furthermore, this finding is a supplement for investors, regulators and researchers in estimating the value relevance and improving the quality of accounting numbers in the context of firm value.
\end{abstract}

Keywords : Information Asymmetry, Value Relevance, Accounting Numbers, Earnings Management, Firm Value

\begin{abstract}
Abstrak
Penelitian ini bertujuan untuk menyajikan bukti apakah kepemilikan institusional mampu menurunkan dampak praktik manajemen laba terhadap nilai perusahaan. Manajemen laba diproksi dengan accrual management, real activity manipulations berbasis abnormal production cost dan abnormal discretionary expenses. Sementara itu, metrik yang dikembangkan Rhodes-Kropf et al (2005) sebagai proksi dari nilai perusahaan dan memiliki keunggulan mendeteksi terjadinya mis-valuasi. Sampel penelitian ini adalah perusahaan manufaktur di Bursa Efek Indonesia yang terdapat kepemilikan institusional. Periode pengamatan selama tahun 2010-2018 dengan data panel 410 observasi sampel. Temuan menunjukkan bahwa adanya kepemilikan institusional dapat memitigasi dampak manajemen laba pada nilai perusahaan. Namun temuan mengejutkan bahwa real activity manipulations berbasis abnormal discretionary expenses berpotensi untuk menghancurkan nilai perusahaan. Dengan kata lain, market menghukum nilai perusahaan. Hasil ini berkontribusi pada wawasan bahwa pentingnya peran
\end{abstract}

\section{Article History \\ Received : 2020-05-22 \\ Revised : :2020-05-29 \\ Accepted : :2020-06-07 \\ @() (0)}

This is an open access article under the CC-BYSA License 
kepemilikan institusional untuk menurunkan asimetri informasi dalam mencegah hancurnya nilai perusahaan. Lebih lanjut, temuan ini sebagai salah satu suplemen bagi investor, regulator maupun peneliti dalam mengestimasi relevansi nilai suatu perusahaan dan meningkatkan kualitas angka akuntansi dalam konteks nilai perusahaan.

Kata kunci: Asimetri Informasi, Relevansi Nilai, Angka Akuntansi, Manajemen Laba, Nilai Perusahaan

\section{Pendahuluan}

Manajer, auditor, investor, sekuritas, auditor, bank, dan para analis berperan dalam memicu misinformasi yang mengakibatkan asimetri informasi (Jensen, 2005). Hal tersebut berimplikasi pada terciptanya ilusi overvalue pada nilai perusahaan (Wibowo \& Fuad, 2017). Saat pasar telah mengetahui bahwa pertumbuhan perusahaan hanyalah ilusi, maka mendorong jatuhnya nilai perusahaan (firm value) karena hilangnya kepercayaan investor (Badertscher, 2011; Jensen, 2005; Marciukaityte \& Varma, 2008). Perubahan FV diindikasikan dari nilai ekuitas yang overvalue yaitu kondisi saat harga saham melebihi underlying value (Badertscher, 2011; Jensen, 2005).

Studi membuktikan bahwa tingkat kepemilikan institusional (institutional ownership) yang lebih tinggi berhubungan dengan rendahnya tingkat asimetri informasi (Boone \& White, 2015). Dengan demikian, hadirnya institutional ownership (IO) mampu menekan asimteri informasi antara manajer dan shareholders sehingga firm value (FV) memiliki value relevance yang tinggi.

Fokus asimetri informasi di penelitian ini dalam konteks nilai perusahaan (FV). Asimteri informasi muncul ketika terdapat perbedaan memiliki informasi diantara para investor (Barakat, Chernobai, \& Wahrenburg, 2014). Lebih lanjut, investor yang memiliki informasi adalah pemegang saham yang besar, analis keuangan, pemberi kredit, dan manajer (Glosten \& Milgrom, 1985). Pemegang saham yang besar seperti 
IO (Woidtke, 2002) memiliki informasi spesifik tentang nilai perusahaan (FV) dibandingkan investor jenis lainnya yang hanya memiliki informasi umum yang dirilis ke publik (Barakat et al., 2014). Berikutnya, IO berpartsipasi aktif dan terlibat dalam monitoring atas rencana dan kinerja perusahaan (Duggal \& Millar, 1999). Jadi, dengan kepemilikan saham yang besar, informasi yang dimiliki IO yang lebih baik dibandingkan investor lainnya dan keterlibatan mengawasi proses bisnis suatu perusahaan.

Studi terdahulu menyajikan bukti empris bahwa IO berhubungan dengan FV. Hadirnya investor saham yang besar berpengaruh terhadap $\mathrm{FV}$ ketika IO dominan mengawasi perusahaan (Ruiz-Mallorquí \& Santana-Martín, 2011). Berikutnya, Elyasiani \& Jia (2010) dan Lin \& Fu (2017) menemukan hubungan positif antara IO dan FV yang ditandai dengan meningkatnya kinerja perusahaan. Bertentangan dengan temuan tersebut, bukti empiris dari
Pakistan menunjukkan bahwa IO tidak berhubungan dengan FV yang direfleksikan dengan financial distress. Jadi, hasil tersebut menandakan bahwa belum ada hasil yang seragam pada hubungan IO dan FV.

Pada sisi lain, IO memiliki kemampuan dalam menentukan FV. Hal ini terjadi karena IO mempunyai keunggulan informasi dan canggih daripada investor lainnya. Dengan demikian, kebebasan manajer dalam mendorong FV melalui manajemen laba menjadi terbatas (Roychowdhury, 2006; Wibowo \& Fuad, 2017; Zang, 2012).

Lebih lanjut, perusahaan yang memiliki kualitas laba yang rendah merupakan refleksi dari tingginya manajemen laba (earnings management). Sedangkan faktor utama dalam menentukan FV adalah kualitas laba maupun pertumbuhan laba. Earnings management (EM) memiliki implikasi pada akrual yang mengakibatkan kualitas akrual rendah (Doyle, Ge, \& Vay, 2007). Kondisi lemahnya kualitas akrual ini 
merupakan indikasi dari buruknya kualitas laba namun tingkat laba semakin meningkat. Ketika EM mampu mendongkrak laba dan ekspektasi pertumbuhannya, maka FV semakin relatif tinggi (Dechow, Hutton, \& Sloan, 2000). Bukti tersebut searah dengan temuan Chaney \& Lewis (1995) yang menyatakan bahwa EM berperan dalam mendorong FV (diproksikan dengan present value dari expected cash flow) ketika terdapat asimetri informasi antara manajer dan investor.

Hasil selanjutnya ditunjukkan Gaio \& Raposo (2011) yang menyajikan bukti empiris berdasarkan sampel 7.000 perusahaan dari 38 negara. Temuan mereka menunjukkan bahwa kualitas laba yang diproksikan dengan kualitas akrual memiliki hubungan positif pada FV yang diukur dengan TobinsQ. Sejalan dengan temuan tersebut, Barton \& Waymire (2004) menemukan keterkaitan antara kualitas laba dan FV (diproksikan dengan price to book ratio). Terakhir, Wibowo \& Fuad (2017) menyajikan bukti empiris bahwa meningkatnya $\mathrm{FV}$ didorong peningkatan EM. FV pada penelitian tersebut menggunakan metrik Rhodes-Kropf, Robinson, \& Viswanathan (2005). Sebagaimana dibuktikan bahwa metrik FV ini handal yaitu dapat menjelaskan $80 \%$ sampai dengan $94 \%$ variasi FV(Rhodes-Kropf et al., 2005).

Namun demikian, penelitian terdahulu belum mempertimbangkan peran IO di dalam hubungan EM dan FV. Penelitian sekarang ini bertujuan memperdalam temuan Wibowo \& Fuad (2017) yang menyarankan pentingnya peran IO di dalam menentukan hubungan antara EM dan FV. Secara khusus, penelitian ini menguji hubungan accrual management (AM), real activity manipulations based on abnormal production costs (RMP), dan real activity manipulations based on abnormal discretionary expenses (RMD) sebagai proksi dari EM terhadap FV dalam konteks adanya IO di dalam kepemilikan perusahaan. 
Hasil penelitian menunjukkan bahwa IO mampu memitigasi pengaruh AM dan RMP sehingga tidak mampu mendorong perubahan FV. Namun demikian, praktik RMD berakibat buruk pada menurunnya nilai perusahaan. Temuan ini mengindikasikan bahwa market mengetahuinya dan menurunkan kepercayaan investor yang berakibat pada jatuhnya FV. Bukti tersebut sebagai isyarat bahwa adanya IO dapat mengurangi tingkat asimetri informasi di Bursa Efek Indonesia.

\section{Tinjauan Pustaka}

\section{1 Asimetri Informasi}

Pengambilan keputusan tentunya didasarkan atas informasi yang tersedia, baik untuk umum/publik maupun untuk tertentu saja. Sebagaimana Stiglitz

menjelaskan bahwa ketika informasi yang diketahui berbeda maka berpotensi menimbulkan asimetri informasi. Penjelasan tersebut mengindikasikan bahwa informasi akan berbeda diantara pengambil keputusan dan mengisyaratkan suatu kondisi asimetri informasi. Subjek yang memiliki informasi berpotensi menghasilkan keputusan yang lebih baik dibandingkan yang lainnya.

Stiglitz (2000) menunjukkan pentingnya konsep asimetri dengan menekankan pada dua jenis informasi. Pertama adalah informasi tentang kualitas dan informasi, bahwa informasi asimetri penting ketika salah satu pihak tidak sepenuhnya menyadari karakteristik pihak lain. Kedua, asimetri informasi penting ketika salah satu pihak mempertimbangkan perilaku atau niat perilaku dari pihak lain. Poin kedua ini mencerminkan bahwa asimetri informasi berkaitan dengan kepentingan pribadi dari perilaku opportunistik manajer.

Asimetri informasi didorong
perilaku manajer dalam mencapai
kepentingan pribadi yang berkaitan
dengan moral hazard (Jensen \&
Meckling, 1976; Ross, 1973).
Selanjutnya, Jensen (2005)
menyatakan bahwa tindakan ini

Asimetri informasi didorong 
dilakukan dengan penciptaan nilai melalui praktik EM. Praktik tersebut pada akhirnya berdampak pada menggelembungnya FV yang melebihi nilai fundamentalnya (overvalue). Hal ini sejalan dengan bukti empiris Chaney \& Lewis (1995) yang menunjukkan bahwa EM mempengaruhi FV ketika manajer dan investor ingin memaksimalkan nilai ketika ada asimetri informasi.

$$
\begin{aligned}
& \text { Hadirnya IO sebagai investor } \\
& \text { di dalam kepemilikan suatu }
\end{aligned}
$$$$
\text { perusahaan diharapkan mampu }
$$
menekan asimetri informasi. Penelitian terdahulu menunjukkan bahwa IO berhubungan dengan lingkungan informasi sehingga meningkatkan kualitas informasi (Bushee \& Noe, 2000). Temuan ini selaras dengan Boone \& White (2015) yang menyatakan bahwa tingginya tingkat IO berhubungan dengan rendahnya tingkat asimetri informasi karena informasi dan produksi perusahaan yang semakin transparan. Dengan demikian, penelitian sekarang ini dibangun berdasarkan kerangka konsep asimetri informasi.

\subsection{Pengembangan Hipotesis}

\subsubsection{Peran Institusional Ownership pada Hubungan Accrual Management dan Firm Value}

$\begin{array}{ccr} & \text { Manajer menyadari peluang } \\ \text { untuk menjalankan EM dalam }\end{array}$
memenuhi proyeksi pasar dan penciptaan nilai bagi perusahaan (Badertscher, 2011). Selanjutnya Gunny (2005) menyatakan bahwa Accrual Management (AM) merupakan salah satu metode dari EM yang berkaitan dengan accounting choice dalam bingkai GAAP/SAK untuk menutupi atau menyembunyikan kinerja ekonomi yang sebenarnya. Kinerja ekonomi tersebut diciptakan dengan laba artifisial yang mengakibatkan menggelembungnya FV (overvalue) melalui praktik AM yang dijalankan manajer (Badertscher, 2011; Dechow, Richardson, \& Tuna, 2000). 
Bukti empiris terdahulu dengan kuat mengindikasikan bahwa AM memiliki hubungan dengan FV. Sebagaimana Hunt, Moyer, Shevlin (2000) menemukan bahwa perubahan AM memiliki hubungan yang kuat dengan market value of equity. Searah dengan itu, menggunakan sampel dari 38 negara, Gaio and Raposo (2010) membuktikan hubungan positif signifikan antara accrual quality dengan FV. Temuan terbaru menunjukkan hasil serupa, Nazir \& Afza (2018) membuktikan bahwa FV dipengaruhi keputusan manajerial dengan melakukan AM.

Lebih lanjut, kehadiran IO dapat meningkatkan fungsi monitoring dan transparansi sehingga menekan potensi asimetri informasi (Boone \& White, 2015). Namun demikian, IO memiliki keterbatasan untuk mengawasi AM karena tidak dapat mengantisipasi future accrual (Xie, 2001). Temuan ini konsisten dengan Zang (2012) yang menunjukkan bahwa IO lebih menekankan pada RM dibanding AM karena RM memiliki konsekuensi jangka panjang pada FV. Dengan kata lain, adanya IO di dalam kepemilikan perusahaan tidak mampu berperan di dalam mengendalikan manajer menjalankan AM untuk meningkatkan FV. Manajer masih leluasa melakukan praktik AM dalam mendorong $\mathrm{FV}$ agar meningkat walaupun terdapat IO dalam kepemilikan perusahaan. Hal ini mengindikasikan bahwa asimteri informasi masih tinggi walaupun terdapat kepemilikian IO. Berdasarkan temuan tersebut maka dalam penelitian ini dirumuskan hipotesis berikut:

H1: Peningkatan/penurunan AM mempengaruhi peningkatan/ penurunan FV.

\subsubsection{Peran Institusional Ownership pada Hubungan Real Activity Management dan Firm Value}

RM memiliki konsekuensi pada cash flow perusahaan ketika manajer ingin mengendalikan output dengan cara mengubah struktur dan waktu operasional, investasi, dan transaksi keuangan (Gunny, 2010; 
Roychowdhury, 2006). Graham, Harvey, \& Rajgopal (2005) membuktikan bahwa $80 \%$ dari responden survei menjalankan Real Activity Manipulation (RM) dengan mengurangi belanja diskresioner seperti pada biaya penelitian \& pengembangan, iklan, dan pemeliharaan dalam mencapai target laba yang telah ditetapkan. Selanjutnya, lebih dari setengahnya (55,3\%) manajer melakukan penundaan pada proyek baru dengan tujuan mencapai target laba walaupun ada nilai jangka panjang yang harus dikorbankan. Lebih lanjut, RM seringkali dijalankan dibandingkan AM. Hal tersebut karena perhatian auditor lebih cenderung pada AM dibandingkan RM, misalnya yang berkaitan dengan harga produk, produksi, dan biaya R\&D (Cohen \& Zarowin, 2010).

Praktik RM dilakukan manajer yang oportunistik dengan tujuan untuk meningkatkan FV. Badertscher (2011) membuktikan bahwa manajer menjalankan RM dalam rangka mempertahankan FV agar terjaga selalu tinggi (overvalue) dalam memenuhi kepentingan pribadinya (bonus). Temuan ini konsisten dengan Efendi, Srivastava, \& Swanson, (2007) yang menunjukkan bahwa perusahaan cenderung memiliki FV yang tinggi ketika terlibat dalam RM. Bukti empiris tersebut diperkuat dengan temuan Abner \& Ferrer (2017) yang menunjukkan bahwa RM mempengaruhi FV pada perusahaan publik di Filipina.

Namun demikian, tindakan RM dibatasi dengan adanya IO di dalam kepemilikan suatu perusahaan. Manajer merasa kesulitan menjalankan RM ketika operasional perusahaan dalam pengawasan IO (Zang, 2012). Hasil tersebut sejalan dengan temuan Bushee (1998) yang membuktikan bahwa perusahaan cenderung mengurangi pengeluaran R\&D (RM) ketika tingkat IO tinggi.

Pada sisi lain, kehadiran IO di dalam kepemilikan perusahaan memiliki peran positif dalam meningkatkan FV (McConnell \& Servaes, 1990; Schmidt \& Fahlenbrach, 
2017). Bukti yang sejalan ditunjukkan Lin \& Fu(2017) menunjukkan bahwa hadirnya IO mampu mendorong peningkatan FV (diproksikan dengan Tobins Q dan ROA) pada perusahaan yang terdaftar di China.

\section{Ulasan}

tersebut

mengindikasikan bahwa upaya manajer di dalam melakukan RM untuk meningkatkan FV dibatasi oleh hadirnya IO. RM yang dilakukan tidak dapat mendorong FV karena IO berperan positif dalam menekan asimteri informasi. Hal ini mengarahkan pada hipotesis null, yaitu sebagai berikut:

H2a: Peningkatan/penurunan RMP tidak mempengaruhi peningkatan/penurunan FV.

H2b: Peningkatan/penurunan RMD tidak mempengaruhi peningkatan/penurunan $\mathrm{FV}$.

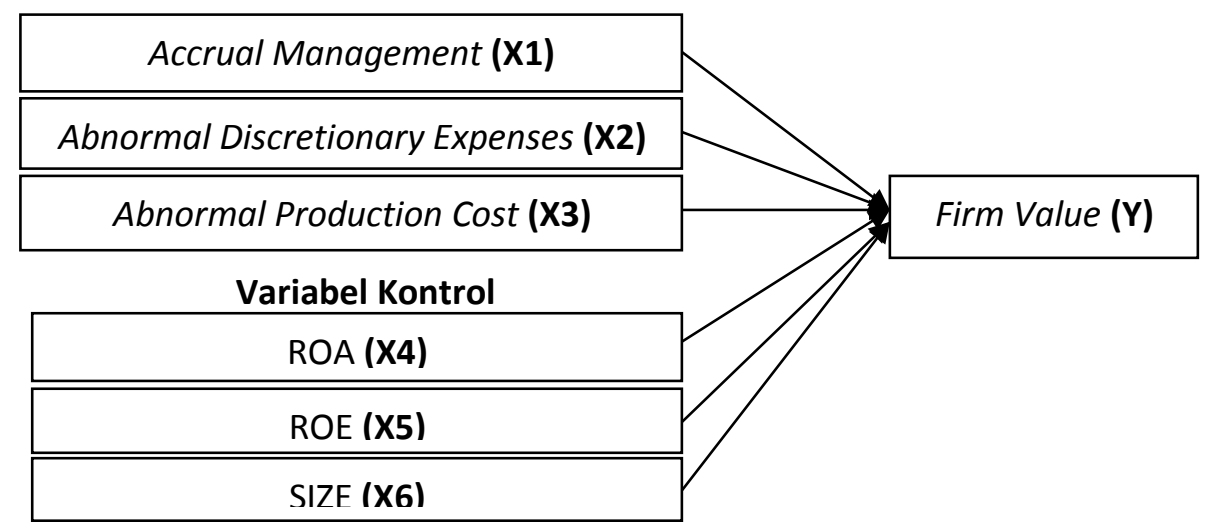

Gambar 1

Model Penelitian Empiris

\section{Metode Penelitian}

\subsection{Populasi dan Sampel}

Penelitian ini memiliki populasi seluruh emiten sektor manufaktur yang terdaftar di Bursa Efek Indonesia (BEI) periode tahun 2010-2018. Kriteria sampel adalah emiten yang mempunyai kepemilikan IO. Selain itu, emiten yang mempublikasikan laporan keuangan dengan data keuangan yang lengkap. Berdasarkan sampling data panel selama 9 tahun terdapat 855 sampel observasi secara keseluruhan (IO dan 
tidak IO). Berikutnya, sampel dalam observasi yang terdapat kepemilikan penelitian ini adalah berdasarkan

\section{Tabel 1}

IO yaitu 410 sampel.

Seleksi Sampel

\begin{tabular}{lc}
\multicolumn{1}{c}{ Karakteristik Sampel } & Jumlah Emiten \\
\hline Emiten manufaktur yang konsisten mempublikasikan laporan keuangan & \\
pertahun (2010-2018) & 141 \\
Data keuangan tidak lengkap & $(46)$ \\
Sampel yang layak pertahun & 95 \\
Sampel data panel 2010-2018 (9 tahun x 95) & $\mathbf{8 5 5}$ \\
Sampel data panel tidak terdapat kepemilikan IO & 455 \\
Sampel data panel terdapat kepemilikan IO & $\mathbf{4 1 0}$ \\
\hline
\end{tabular}
Sumber: Data IDX (2010-2018)

3.2 Definisi Operasional dan dengan 94\% variasi FV. Penelitian

\section{Pengukuran Variabel}

\subsubsection{Firm Value (FV)}

Pengukuran firm value (FV) mengikuti indikator Rhodes-Kropf et al (2005). Metrik ini mempunyai keunggulan yaitu estimasi yang kuat dan mampu memprediksi sampai $\mathrm{kk}$

Mengikuti Rhodes-Kropf et al (2005), prosedur pengukuran FV adalah sebagai berikut:

1) Melakukan dekomposisi market to book value (M/B) menjadi dua komponen:

$$
M / B=M / V \times V / B
$$

dimana $M / V$ adalah indikasi misvaluation dan $V / B$ adalah refleksi growth opportunistis.

2) Proses dekomposisi persamaan (1) dalam bentuk logaritma, huruf kecil merupakan representasi dari logarithm value.

$(m-b)=(m-v)+(v-b)$ 
dimana $m$ adalah market value, $b$ adalah book value, dan $v$ adalah fundamental value.

3) Menjalankan dekomposisi persamaan 2 menjadi tiga komponen untuk perusahaan $i$ dan tahun $t$ :

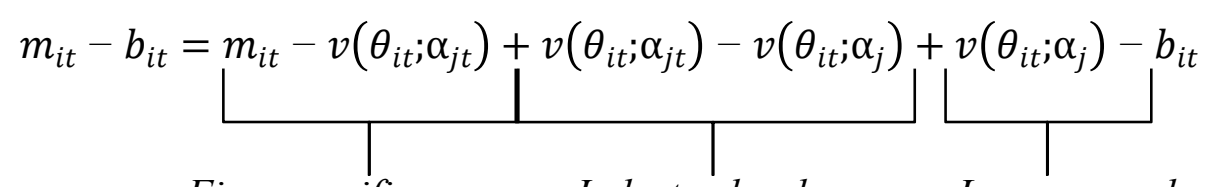

Firm-specific-error Industry-level error Long-run valuation

4) Persamaan 3 dapat dioperasionalkan dengan estimasi $v\left(\theta_{i t} ; \alpha_{j t}\right)$ dan $v\left(\theta_{i t} ; \alpha_{j}\right)$ dan didekomposisi menjadi :

$\mathrm{m}_{\mathrm{it}}=\alpha_{0 \mathrm{jt}}+\alpha_{1 \mathrm{jt}} \mathrm{b}_{\mathrm{it}}+\alpha_{2 \mathrm{jt}} \mathrm{ni}_{\mathrm{it}}^{+}+\alpha_{3 \mathrm{jt}} \mathrm{I}_{(<0)} \mathrm{ni}_{\mathrm{it}}^{+}+\alpha_{4 \mathrm{jt}} \mathrm{LEV}_{\mathrm{it}}+\varepsilon_{\mathrm{it}}$

dimana $\mathrm{m}_{\mathrm{it}}$ adalah $\log$ value of market value, $\mathrm{b}_{\mathrm{it}}$ adalah $\log$ value of book value, $\mathrm{ni}_{\mathrm{it}}^{+}$ adalah $\log$ value of net income, $\mathrm{I}_{(<0)}$ adalah bernilai 1 jika net income negatif dan 0 jika sebaliknya, dan $\mathrm{LEV}_{\mathrm{it}}$ adalah leverage ratio.

$$
\text { Regresi cross-section } \quad \frac{T A_{i t}}{A_{i t-1}}=\alpha_{1}\left(\frac{1}{A_{t-1}}\right)+\alpha_{2}\left(\Delta R_{t-1}\right)+
$$
dijalankan pada persamaan 4 untuk $\quad \alpha_{3}\left(\frac{P P E_{t}}{A_{t-1}}\right)+\varepsilon_{t}$

mengestimasi FV tiap perusahaan pertahun. Jika hasil $\ln (\mathrm{M} / \mathrm{V})$ positif maka FV disimpulkan overvalue dan jika negatif maka FV diasumsikan undervalue.

\subsubsection{Accrual Management (AM)}

Perubahan periode berjalan yang terjadi dalam penjualan kredit adalah objek EM maka pengukuran pada penelitian ini mengadopsi indikator yang dikembangkan Dechow, Sloan, \& Sweeney (1995) yaitu Modified Jones Model. dimana $T A_{i t}$ adalah total accrual perusahaan i dalam periode $\mathrm{t}, A_{t-1}$ adalah total asset pada periode $\mathrm{t}$, $\Delta R_{t-1}$ perubahan penjualan bersih pada periode $t$, dan PPEt adalah property, plants, dan equipment. Pada tahap selanjutnya, estimasi regresi secara cross-sectional dioperasionalkan pada persamaan 5 . Ini bertujuan untuk mendapatkan besaran nilai AM setiap perusahaan pada setiap tahunnya. Nilai 
residualnya untuk mengetahui besaran AM.

\subsubsection{Real Activity Management (RM)}

Variabel RM pada penelitian ini dikukur dengan abnormal production cost (RMP) dan abnormal discretionary expenses (RMD) yang mengikuti metrik Roychowdhury (2006). Ukuran tersebut terbukti dapat memprediksi RM dengan tingkat akurasi yang relatif tinggi (Braam, Nandy, Weitzel, \& Lodh, 2013; Zang, 2012).

Selanjutnya, abnormal discretionary expenses (RMD) diestimasi menggunakan regresi crosssection (Roychowdhury, 2006):

$\frac{D I S X_{t}}{A_{t-1}}=\propto_{0}+\propto_{1}\left(\frac{1}{A_{t-1}}\right)+\propto_{2}\left(\frac{S_{t-1}}{A_{t-1}}\right)+$ $\varepsilon_{t}$

dimana DISXt adalah discretionary expenses (yaitu, jumlah pengeluaran R\&D, Advertising, dan SG\&A) pada tahun t. At-1 adalah asset totalpada tahun $\mathrm{t}-1$. St adalah net sales pada tahun $\mathrm{t}-1$. diukur dengan nilai residual merupakan besaran abnormal discretionary expenses. Tinggi rendahnya nilai residual merupakan indikasi tinggi rendahnya tingkat abnormal discretionary expenses.

$$
\text { Sedangkan }
$$

abnormal

production cost (RMP) diukur menggunakan regresi cross-section (Roychowdhury, 2006):

$\frac{P R O D_{t}}{A_{t-1}}=\propto_{0}+\propto_{1}\left(\frac{1}{A_{t-1}}\right)+\propto_{2}\left(\frac{S_{t}}{A_{t-1}}\right)+$ $\propto_{3}\left(\frac{\Delta S_{t}}{A_{t-1}}\right)+\propto_{4}\left(\frac{\Delta S_{t-1}}{A_{t-1}}\right)+\varepsilon_{t}$

dimana PRODt adalah cost of goods sales (COGS) pada tahun $\mathrm{t}$ dan perubahan inventory dari t-1 sampait; At-1adalah asset total pada tahun t-1; St adalah net sales pada tahun $\mathrm{t}$, dan $\Delta$ St adalah perubahan net sales dari tahun $\mathrm{t}-1$ sampai t. Jika residual tinggi (rendah) maka menandakan tinggi (rendah) abnormal production cost. Dengan kata lain, tingginya residu menandakan tingginya tingkat kelebihan persediaan. Hal ini mengakibatkan peningkatan laba dengan cara menekan tingkat COGS.

\subsubsection{Variabel Kontrol}

Perbedaan karakteristik perusahaan model penelitian ini 
dikendalikan dengan beberapa variabel kontrol (ROA, ROE, dan SIZE). SIZE memiliki hubungan positif dengan FV yang diproksikan dengan q-ratio (Ameer, 2012). Temuan selaras menemukan adanya hubungan positif antara SIZE dan FV yang di proksikan dengan Tobin's- $Q$ (Davydov, Nikkinen, \& Vähämaa, 2014). Temuan lainnya membuktikan bahwa ROA dan ROE memiliki hubungan positif dengan FV yang diproksikan dengan price to earnings ratio (Houmes, Foley, \& Cebula, 2013).

\subsection{Metode Analisa data}

Berdasarkan pertimbangan bahwa penelitian ini memiliki sampel besar yaitu 410 observasi maka tidak dijalankan uji normalitas. Asumsi ini konsisten dengan Gujarati (2004) yang menyatakan bahwa asumsi normalitas berperan penting jika sampel kurang dari 100 observasi (ukuran sampel kecil). Sedangkan dalam kondisi ukuran sampel cukup besar maka asumsi normalitas dapat diabaikan. Pada sampel besar, secara asymptotic estimator OLS masih terdistribusi normal (unbiased) dan uji $\mathrm{t}$ dan $\mathrm{F}$ masih berlaku walaupun redisual tidak terdistribusi secara normal (Gujarati, 2004).

Sebagaimana Gujarati (2004) menjelaskan bahwa pada data crosssection dan time-series terdapat masalah khusus yaitu heteroskedastisitas. Dengan demikian, mengingat penelitian ini menggunakan data panel, maka uji heteroskedastisitas dapat diabaikan. Sedangkan autokorelasi di uji dengan Durbin Watson (DW) dan koefisien korelasi digunakan uji multikolinearitas.

$$
\text { Selanjutnya, persamaan }
$$

common OLS yang diusulkan pada penelitian ini adalah sebagai berikut:

$F V_{i t}=\alpha+\beta_{1} A M_{i t}+\beta_{2} R M P_{i t}+$ $\beta_{3} R M D_{i t}+\beta_{4} R O A+\beta_{5} R O E_{i t}+$ $\beta_{6} S I Z E_{i t}+\varepsilon_{i t}$ dimana $F V_{i t}$ adalah firm value berdasarkan metrik overvalue RhodesKropf et al(2005), $R M P_{i t}$ adalah real activity manipulation berbasis abnormal production cost (Roychowdhury, 2006), $R M D_{i t}$ adalah real activity manipulation berbasis 
abnormal discretionary expenses (Roychowdhury, 2006), $R O A_{i t}$ adalah rasio return on asset, $R O E_{i t}$ adalah rasio return on equity, dan $S I Z E_{i t}$ adalah natural log dari total asset.

\section{Hasil Penelitian dan Pembahasan}

\subsection{Deskriptif Statistik}

Tabel 2 menunjukkan mean (median) FV memiliki nilai positif dan bermakna bahwa FV lebih tinggi daripada fundamental value. Nilai positif tersebut mengindikasikan bahwa FV dalam kondisi overvalue

(Rhodes-Kropf et al., 2005). Berikutnya, mean AM adalah -0.001 dan ini merupakan bukti bahwa ruang gerak manajer menjalankan AM sangat terbatas. IO telah menjalankan fungsi monitoring dengan baik. Hal ini tercermin dari nilai mean RMP dan RMD yang sangat kecil yaitu masingmasing -0.019 dan 0.036 . Selanjutnya tampak bahwa tingkat adanya profitabilitas dan kinerja keuangan yang baik pada rata-rata sampel. Hal ini ditunjukkan dengan nilai positif pada mean dari ROA dan ROE.

Tabel 2

Statistik Deskriptif

\begin{tabular}{|c|c|c|c|c|c|c|c|}
\hline & $\mathrm{FV}$ & AM & RMP & RMD & ROA & ROE & SIZE \\
\hline Mean & 0.899740 & -0.001468 & -0.019706 & 0.036024 & 0.017974 & 0.019872 & 6.118023 \\
\hline Median & 0.895404 & -0.000192 & -0.063556 & 0.068042 & 0.026038 & 0.056790 & 6.124065 \\
\hline Maximum & 1.068827 & 0.512720 & 7.938506 & 0.389776 & 0.579876 & 3.448316 & 7.839461 \\
\hline Minimum & 0.808676 & -1.230994 & -2.438966 & -0.376721 & -0.670078 & -9.670751 & 4.678373 \\
\hline Std. Dey. & 0.038431 & 0.140004 & 0.577396 & 0.118249 & 0.111996 & 0.772746 & 0.602882 \\
\hline Skewness & 0.816248 & -2.410672 & 6.547169 & -1.529653 & -1.490318 & -7.040277 & 0.217921 \\
\hline Kurtos is & 4.558880 & 24.08095 & 92.66449 & 5.794685 & 13.43875 & 88.17135 & 3.294655 \\
\hline Jarque-Bera & 87.04210 & 7989.050 & 140274.4 & 293.3144 & 2013.300 & 127312.2 & 4.728337 \\
\hline Probability & 0.000000 & 0.000000 & 0.000000 & 0.000000 & 0.000000 & 0.000000 & 0.094027 \\
\hline Sum & 368.8935 & -0.601849 & -8.079307 & 14.76964 & 7.369412 & 8.147712 & 2508.390 \\
\hline Sum Sq. Dey. & 0.604068 & 8.016890 & 136.3550 & 5.718965 & 5.130095 & 244.2285 & 148.6578 \\
\hline Observations & 410 & 410 & 410 & 410 & 410 & 410 & 410 \\
\hline
\end{tabular}

Sumber: Output Eviews Versi 8

Sementara itu, tabel 30.346 dengan signifikansi 0.00. Hal ini menunjukkan korelasi antara AM dan menandakan bahwa praktik AM ROA memiliki nilai tertinggi, yaitu berhubungan erat dengan ROA. 
Tabel 3

Koefisien Korelasi

\begin{tabular}{|c|c|c|c|c|c|c|c|}
\hline & \multirow[b]{2}{*}{ AM } & & \multirow[b]{2}{*}{ ROA } & \multirow[b]{2}{*}{ ROE } & \\
\hline $\begin{array}{l}\text { Correlation } \\
\text { Probability }\end{array}$ & FV & & RMP & RMD & & & SIZE \\
\hline \multirow[t]{2}{*}{ FV } & 1.000000 & & & & & & \\
\hline & $\cdots$ & & & & & & \\
\hline & & & & & & & \\
\hline \multirow[t]{2}{*}{ AM } & -0.006743 & 1.000000 & & & & & \\
\hline & 0.8917 & $\ldots$ & & & & & \\
\hline & & & & & & & \\
\hline \multirow[t]{2}{*}{ RMP } & 0.043804 & -0.102459 & 1.000000 & & & & \\
\hline & 0.3763 & 0.0381 & $\ldots$ & & & & \\
\hline & & & & & & & \\
\hline \multirow[t]{2}{*}{ RMD } & -0.176698 & -0.019655 & -0.187650 & 1.000000 & & & \\
\hline & 0.0003 & 0.6915 & 0.0001 & $\ldots$ & & & \\
\hline \multirow[t]{2}{*}{$\mathrm{ROA}$} & -0.046550 & 0.346059 & -0.250506 & -0.118194 & 1.000000 & & \\
\hline & 0.3471 & 0.0000 & 0.0000 & 0.0167 & - & & \\
\hline \multirow[t]{2}{*}{ ROE } & 0.040445 & 0.085174 & 0.001340 & -0.033355 & 0.188065 & 1.000000 & \\
\hline & 0.4141 & 0.0850 & 0.9784 & 0.5006 & 0.0001 & $\cdots$ & \\
\hline \multirow[t]{2}{*}{ SIZE } & 0.161235 & -0.032773 & -0.071526 & 0.025596 & 0.063746 & 0.009304 & 1.000000 \\
\hline & 0.0011 & 0.5081 & 0.1483 & 0.6053 & 0.1977 & 0.8510 & $\ldots$ \\
\hline
\end{tabular}

Sumber: Output Eviews Versi 8

\subsection{Pengujian Hipotesis}

Berdasarkan tabel 3 menunjukkan bahwa tidak ada masalah multikolinearitas pada model yang dibuktikan dengan nilai korelasi < 0,8. Sedangkan pada tabel 4 nilai DW sedikit dibawah 2 (yaitu 1.221) dan model ini terkandung masalah autokorelasi. Lebih lanjut, tabel 4 menunjukkan nilai adjusted Adj-R $R^{2}$ 0.054. Hasil ini mengindikasikan bahwa variasi AM, RMP, RMD, dan variabel kontrol dapat menjelaskan variasi $\mathrm{FV}$ sebesar 5.4\% dan selebihnya dijelaskan variabel lain diluar model ini. Sedangkan F-Statistic memiliki $\rho<0.01$ yang berarti signifikan. 
Tabel 4

Analisis Regresi OLS

\begin{tabular}{|c|r|r|r|r|}
\hline \hline Variable & Coefficient & Std. Error & t-Statistic & Prob. \\
\hline \hline AM & 0.006823 & 0.014105 & 0.483714 & 0.6289 \\
\hline RMP & -0.000123 & 0.003403 & -0.036148 & 0.9712 \\
\hline RMD & -0.062067 & 0.016166 & -3.839394 & 0.0001 \\
ROA & -0.033758 & 0.018670 & -1.808151 & 0.0713 \\
\hline ROE & 0.002430 & 0.002439 & 0.996178 & 0.3198 \\
\hline SIZE & 0.011004 & 0.003083 & 3.568852 & 0.0004 \\
\hline C & 0.835220 & 0.018927 & 44.12814 & 0.0000 \\
\hline \hline R-squared & 0.067884 & Mean dependent var & 0.899740 \\
\hline Adjusted R-squared & 0.054007 & S.D. dependent var & 0.038431 \\
\hline S.E. of regression & 0.037379 & Akaike info criterion & -3.718500 \\
\hline Sum squared resid & 0.563062 & Schwarz criterion & -3.649931 \\
\hline Log likelihood & 769.2925 & Hannan-Quinn criter. & -3.691372 \\
\hline F-statistic & 4.891630 & Durbin-Watson stat & 1.221381 \\
\hline Prob(F-statistic) & 0.000077 & & & \\
\hline \hline
\end{tabular}

Sumber: Output Eviews Versi 8

Hasil merefleksikan bahwa dengan adanya IO maka upaya manajer melalui praktik AM tidak mampu mendorong FV. Bukti ini ditunjukkan pada tabel 4 dengan nilai koefisien AM sebesar $0.006(\rho>0.10)$ atau tidak signifikan. Temuan ini bertentangan dengan hipotesis yang diusulkan bahwa AM dapat mempengaruhi FV. Jadi, dapat disimpulkan bahwa H1 ditolak.

Selanjutnya, hipotesis H2a tidak dapat ditolak yang ditunjukkan dengan nilai koefisien RMP yang tidak signifikan (0.0001, $\rho>0.10)$. Hasil ini menunjukkan bahwa IO mampu menekan dampak RMP terhadap FV. Dengan demikian, peningkatan/ penurunan praktik RMP tidak dapat mempengaruhi peningkatan/penurunan $\mathrm{FV}$.

Bukti empiris selanjutnya menunjukkan bahwa nilai koefisien RMD signifikan (-0.062, $\rho<0.01)$. Peningkatan/penurunan praktik RMD dapat mengakibatkan peningkatan/ penurunan FV. Dengan demikian, hipotesis $\mathrm{H} 2 \mathrm{~b}$ yang diusulkan ditolak.

Sementara itu, ROA memiliki pengaruh yang signifikan dalam menentukan FV. Demikian pula dengan variabel kontrol SIZE. Namun demikian, ROE tidak signifikan mempengaruhi FV dalam sampel penelitian ini. Temuan ini merefleksikan bahwa rasio keuangan 
(khusunya ROA dan SIZE) memiliki relevansi yang kuat dalam menentukan FV.

\subsection{Pembahasan}

Pengujian empiris membuktikan bahwa IO berperan dalam mempengaruhi hubungan antara AM dan FV. Temuan ini mengejutkan karena perubahan pada AM tidak dapat menentukan perubahan FV pada sampel IO ini. Sebagaimana diuraikan sebelumnya bahwa IO lebih menekankan pada RM dan tidak dapat mengantisipasi future accrual (Xie, 2001; Zang, 2012). Hal ini kemungkinan terjadi karena dalam sampel IO terdapat audit yang berkualitas. Manajer tidak dapat menciptakan nilai dalam mendongkrak FV melalui AM. Ini juga menandakan bahwa dengan adanya IO dalam kepemilikan perusahaan maka dapat menjamin adanya kualitas audit yang tinggi. Dengan kata lain, IO mampu memitigasi asimteri informasi atas praktik AM dan dampak buruknya pada FV. Informasi tersedia dengan baik dan mis-informasi diantara pengambil keputusan dapat ditekan dengan baik.

Bukti empiris selanjutnya menyajikan bukti bahwa tindakan RMP tidak dapat mempengaruhi FV. Aktivitas produksi yang berlebihan (RMP) dapat diawasi IO dengan baik yang mengakibatkan manajer tidak leluasa menjalankannya dalam rangka meningkatkan FV. Lebih lanjut, temuan ini menandakan bahwa rendahnya tingkat asimetri informasi dalam sampel IO ini. IO memiliki keunggulan informasi yang spesifik dibandingkan investor lainnya serta keterlibatannya dalam monitoring yang berkaitan dengan kinerja perusahaan. Hal inilah yang menciptakan lingkungan informasi yang handal bagi pengambil keputusan atau investor. Kualitas informasi meningkat yang merupakan indikasi rendahnya tingkat asimetri informasi. Pada sisi lain, kualitas informasi yang baik dapat membatasi manajer menjalankan RMP (Roychowdhury, 2006; Wibowo \& Fuad, 2017; Zang, 2012). 
Hasil ini sejalan dengan RuizMallorquí \& Santana-Martín (2011) yang menyatakan bahwa hadirnya IO dominan mengawasi perusahaan yang berpengaruh terhadap FV. Selain itu, temuan ini didukung Boone \& White (2015) yang menyatakan bahwa tingkat asimetri informasi semakin rendah karena informasi dan produksi perusahaan yang semakin transparan ketika IO ada dalam kepemilikan perusahaan.

Temuan menarik ditunjukkan dengan peningkatan RMD yang justru membawa FV semakin menurun. Namun demikian, market merespon ini dengan negatif yang menandakan hilangnya kepercayaan investor melihat pertumbuhan perusahaan yang semu. Ilusi pertumbuhan perusahaan mendorong hancurnya nilai perusahaan (FV) yang merupakan konsekuensi dari jatuhnya kepercayaan investor (Badertscher, 2011; Jensen, 2005; Marciukaityte \& Varma, 2008) Tingkat mis-informasi pada praktik RMD yang telah dijalankan dapat ditekan dengan baik. Dengan demikian, tingkat asimetri informasi sangat rendah pada hubungan tersebut.

Bersamaan dengan adanya IO di dalam perusahaan mengakibatkan manipulasi laba (RMD) melalui diskresi pengurangan belanja research and development (R\&D), advertising, maupun selling, general, administrative (SG\&A) dapat dideteksi market dengan baik. Pada akhirnya, market menghukum ini dengan dampak negatif pada FV. Temuan ini memiliki makna bahwa IO mampu menekan asimetri informasi atas FV yang dicetuskan melalui RMD.

\section{Simpulan, Implikasi, dan Keterbatasan Penelitian}

\subsection{Simpulan}

Penelitian ini memperdalam temuan sensitivity test Wibowo \& Fuad (2017) yang memberikan petunjuk bahwa IO mempengaruhi hubungan antara EM dan FV di Bursa Efek Indonesia periode 2010-2014. Namun demikian, penelitian ini melanjutkan temuan tersebut dalam kerangka asimetri informasi yang berfokus pada FV. Pengukuran FV mengadopsi 
indikator Rhodes-Kropf et al (2005) dan kemampuan prediksi yang kuat dalam mengestimasi variasi FV. Sementara itu, EM diproksikan dengan AM dan diukur dengan Modified Jones Model. Selain itu, EM juga diproksikan dengan abnormal production cost (RMP) dan abnormal discretionary expenses (RMD) megadopsi model Roychowdhury (2006).

Secara umum, temuan menunjukkan bahwa IO berperan dalam memitigasi asimetri informasi atas FV. Lebih lanjut, temuan berkontribusi pada literatur kualitas accounting numbers yang membuktikan bahwa asimetri informasi atas FV dapat ditekan ketika IO ada dalam kepemilikan perusahaan. Hal ini tentunya akan berdampak pada meningkatnya value relevance atas informasi akuntansi (khususnya FV). Secara khusus, hasil membuktikan bahwa adanya IO mampu membatasi dampak praktik RMP dalam meningkatkan FV. Lebih lanjut, temuan yang sangat menarik menunjukkan bahwa praktik RMD mengakibatkan jatuhnya FV.

\subsection{Implikasi}

Bukti empiris yang menunjukkan keberhasilan peran IO dalam menekan asimetri informasi melalui tiga metode EM. Temuan ini berimplikasi pada peneliti, investor/manajer, dan regulator bahkan market. Bagi peneliti, temuan ini memberikan petunjuk bahwa adanya IO dapat menjadi sinyal tingkat asimetri informasi yang rendah. Bagi investor, pengawasan IO yang baik membawa sinyal good news untuk berinvestasi. Sedangkan bagi regulator, mengingat pentingnya peran IO maka sebaiknya membuka pintu yang luas dan kemudahan (khususnya insentif) kepada IO untuk berinvestasi di Bursa Efek Indonesia.

\subsection{Keterbatasan Penelitian}

Pengujian pada H1 membuktikan AM tidak berpegaruh signifkan terhadap FV. Temuan ini menjadi petunjuk kemungkinan adanya kualitas audit yang baik pada sampel IO dalam penelitian ini. Oleh sebab itu, maka penting untuk melakukan sensitivity test pada sampel IO yang 
menyertakan variabel kualitas audit pada penelitian mendatang.

Pada sisi lain, penelitian ini mengasumsikan bahwa karakteristik semua IO adalah sama. Agenda penelitian selanjutnya diharapkan dapat menguji model yang dapat menjelaskan IO secara lebih heterogen berdasarkan karakteristiknya agar hasil dapat menghasilkan wawasan yang lebih mendalam. Sebagai contoh, tipe IO yaitu quasi-indexer, transient, dedicated, passive, dan active (Boone \& White, 2015; Bushee \& Noe, 2000; Schmidt \& Fahlenbrach, 2017).

\section{DAFTAR PUSTAKA}

Amin, A. (2007). Pendeteksian Earnings Management, Underpricing dan Pengukuran Kinerja Perusahaan yang Melakukan Kebijakan Initial Public Offering (IPO) di Indonesia. In Simposium Nasional Akuntansi $X$.

Baber, W. R., Fairfield, P. M., \& Haggard, J. A. (1991). The Effect of Concern About Reported Income on Discretionary Spending Decisions: The Case of Research and Development. The Accounting Review, 66(4), 818-829.
Badertscher, B. A. (2011). Overvaluation and the Choice of Alternative Earnings Management Mechanisms. The Accounting Review, 86(5), 1491-1518. doi:10.2308/accr-10092

Barton, J., \& Simko, P. J. (2002). The Balance Sheet as an Earnings. The Accounting Review, 77(Supplement), 1-27.

Boone, A. L., \& White, J. T. (2015). The Effect of Institutional Ownership on Firm Transparency and Information Production. Journal of Financial Economics.

Braam, G., Nandy, M., Weitzel, U., \& Lodh, S. (2013). Accrual-based and real earnings management and political connections. International Journal of Accounting, (2015).

Burgstahler, D., \& Dichev, I. (1997). Earnings Management to Avoid Earnings Decreases and Losses. Journal of Accounting and Economics, 24, 99-126.

Burnett, B. M., Cripe, B. M., Martin, G. W., \& McAllister, B. P. (2012). Audit Quality and the Trade-off Between Accretive Stock Repurchases and Accrual-based Earnings Management. Accounting Review, 87(6), 1861-1884.

Bushee, B. J., \& Noe, C. F. (2000). Corporate Disclosure Practices, Institutional Investors, and Stock 
Return Volatility. Journal of Accounting Research, 38, 171-202.

Choy, H. L. (2012). Assessing Earnings Management Flexibility. Review of Accounting and Finance, 11(4), 340-376.

Cohen, D. A., Dey, A., \& Lys, T. Z. (2008). Real and Accrual-Based Earnings Management in the Preand Post-Sarbanes-Oxley Periods. The Accounting Review, 83(3), 757-787.

Cohen, D. A., \& Zarowin, P. (2010). Accrual-based and Real Earnings Management Activities Around Seasoned Equity Offerings. Journal of Accounting and Economics, 50(1), 2-19.

Dechow, P. M., Sloan, R. G., \& Sweeney, A. P. (1995). Detecting Earnings Management. The Accounting Review, 70(2), 193225. Retrieved from http://www.jstor.org/stable/248303। nhttp://www.jstor.org/stable/pdfplu s/248303.pdf?acceptTC $=$ true

Defond, M. L., \& Park, C. W. (1997). Smoothing Income in Anticipation of Future Earnings. Journal of Accounting and Economics, 23, 115-139.

Graham, J. R., Harvey, C. R., \& Rajgopal, S. (2005). The Economic Implications of Corporate Financial Reporting. Journal of Accounting and Economics, 40(1-3), 3-73.
Gunny, K. (2005). What Are the Consequences of Real Earnings Management? University of California, Barkeley.

Gunny, K. (2010). The Relation Between Earnings Management Using Real Activities Manipulation and Future Performance: Evidence from Meeting Earnings Benchmarks. Contemporary Accounting Research, 27(3), 855888.

Healy, P. M. (1985). The Effect of Bonus Schemes on Accounting Decisions. Journal of Accounting and Economics, 7, 85-107.

Healy, P. M., \& Wahlen, J. M. (1999). A Review of the Earnings Management Literature and Its Implications for Standard Setting. Accounting Horizons, 13(4), 365383.

Jensen, M. C. (2005). Agency Cost of Overvalued Equity. Financial Management, 5-19.

Jensen, M. C., \& Meckling, W. H. (1976). Theory of The Firm: Managerial Behavior, Agency Cost and Ownership Structure. Journal of Financial Economics, 3(4), 305360.

Jensen, M. C., \& Meckling, W. H. (1976). Theory of the firm: Managerial behavior, agency costs and ownership structure. Journal of 
Financial Economics, 3(4), 305360.

Kasznik, R. (1999). On the Association Between Voluntary Disclosure and Earnings Management. Journal of Accounting Research, 37(1), 57-81. Retrieved from http://ezproxy.library.capella.edu/l ogin?url=http://search.ebscohost.co $\mathrm{m} / \operatorname{login}$. aspx?direct $=$ true $\& \mathrm{db}=\mathrm{b}$ th $\& \mathrm{AN}=2205751 \&$ site $=$ ehost live \&scope $=$ site

Kirschenheiter, M., \& Melumad, N. . (2002). Can "Big Bath" and Earnings Smoothing Co-exist as Equilibrium Financial Reporting Strategies? Journal of Accounting Research, 40(3), 761-796. Retrieved from http://search.ebscohost.com/login.a spx?direct $=$ true $\& \mathrm{db}=$ buh $\& A N=66$ 82588\&lang $=$ pt-br\&site $=$ ehost-live

Lambright, K. T. (2009). Agency Theory and Beyond: Contracted Providers' Motivations to Properly Use Service MonitoringTools. Journal of Public Administration Research and Theory, 19(2), 207227.

Marciukaityte, D., \& Varma, R. (2008). Consequences of Overvalued Equity: Evidence from Earnings Manipulation. Journal of Corporate Finance, 14, 418-430.

Morris, R. D. (1987). Signalling, Agency Theory and Accounting
Policy Choice. Accounting and Business Research, 18(69), 47-56.

Rhodes-Kropf, M., Robinson, D. T., \& Viswanathan, S. (2005). Valuation Waves and Merger Activity: The Empirical Evidence. Journal of Financial Economics, 77, 561-603.

Roychowdhury, S. (2006). Earnings Management Through Real Activities Manipulation. Journal of Accounting and Economics, 42(3), 335-370.

doi:10.1016/j.jacceco.2006.01.002

Schmidt, C., \& Fahlenbrach, R. (2017). Do Exogenous Changes in Passive Institutional Ownership Affect Corporate Governance and Firm Value? Journal of Financial Economics, 124(2), 285-306.

Teoh, S. H., Welch, I., \& Wong, T. J. (1998). Earnings Management and the Underperformance of Seasoned Equity Offerings. Journal of Financial Economics, 50(October 1995), 63-99.

Ujiyantho, M. A., \& Pramuka, B. A. (2007). Mekanisme Corporate Governance, Manajemen Laba, dan Kinerja Keuangan. In Simposium Nasional Akuntansi X (pp. 1-26).

Watts, R. L., \& Zimmerman, J. L. (1990). Positive Accounting Theory: A Ten Year Perspective. The Accounting Review, 65(1), 131-156. 
Wibowo, A. S., \& Fuad, F. (2017). Bukti Ilusi Pertumbuhan di Bursa Efek Indonesia: Hubungan Earnings Management dan Firm Value. In Simposium Nasional Akuntansi XX Jember-AKPM 060 (pp. 1-22).

Woo, C. Y. (1983). Evaluation of the Strategies and Performance of Low ROI Market Share Leaders : Summary. Strategic Management Journal, 4, 123-135.

Xie, H. (2001). The Mispricing of Accruals Abnormal. The
Accounting Review, 76(3), 357373.

Xu, R. Z., Gary, K. T., \& Dugan, M. T. (2007). Review of Real Earnings Management Literature. Journal of Accounting Literature, 26, 195228.

Zang, A. Y. (2012). Evidence on the Trade-Off between Real Activities Manipulation and Accrual-Based Earnings Management. The Accounting Review, 87(2), 675703. 